\title{
EFFECT OF DIMETHOATE (AN ORGANOPHOSPHATE INSECTICIDE) ON THE REPRODUCTIVE SYSTEM AND FERTILITY OF ADULT MALE RAT
}

\author{
${ }^{1}$ Ferdinand Ngoula, ${ }^{2}$ Pierre Watcho, ${ }^{1}$ Augustave Kenfack, ${ }^{2}$ Joseph N'zouk Manga, \\ ${ }^{1}$ Henry Fualefac Defang, ${ }^{3}$ Kamtchouing Pierre and ${ }^{1}$ Tchoumboue Joseph \\ ${ }^{1}$ Department of Animal Science, \\ Faculty of Agronomy and Agricultural Sciences, University of Dschang, PO Box: 188, Cameroon \\ ${ }^{2}$ Department of Animal Biology, Faculty of Science, University of Dschang, PO. Box: 377, Cameroon \\ ${ }^{3}$ Department of Animal Biology and Physiology, Faculty of Science, University of Yaounde I, PO. Box: 812, Cameroon
}

Received 2013-12-31; Revised 2014-01-13; Accepted 2014-02-13

\begin{abstract}
The pesticides are one of the most potentially harmful chemicals liberated in the environment in an unplanned manner. Dimethoate is widely used as a potent pesticide in many countries and has been shown to produce some adverse health effects. In the present study, we investigated the effect of dimethoate (an organophosphate insecticide) on the reproductive system and fertility of male rats and the possible mechanism underlining its action. Twenty four adult Wistar male rats were divided into 4 groups of 6 animals per group and force-fed with $0,3.66,5.50$ and $11 \mathrm{mg} \mathrm{kg}^{-1}$ body weight of dimethoate for 90 days. At 80 days of treatment, each males was allows to mate with two primiparous cyclic females. The results showed a significant decrease $(\mathrm{p}<0.05)$ of body weight gain in rats gavaged with dimethoate compared to control. In addition, this insecticide at the doses of $3.66,5.5$ and $11 \mathrm{mg} \mathrm{kg}^{-1}$ caused a significant $(\mathrm{p}<0.05)$ increase of the relative weight of epididymis. Dimethoate at its highest dose caused a decrease in the relative weights of testes and ventral prostate. The doses $3.66,5.50$ and $11.00 \mathrm{mg} \mathrm{kg}^{-1}$ body weight of dimethoate caused a significant decrease $(\mathrm{p}<0.05)$ of the sperm concentration and motility. The level of protein and cholesterol in the serum and testes as well as the activity of prostatic acid phosphatase decreased significantly $(\mathrm{p}<0.05)$ in rats treated with dimethoate compared to control. Fertility, gestation and parturition indices as well as the litter size decreased significantly in animals treated with 5.50 and $11.00 \mathrm{mg} \mathrm{kg}^{-1}$ body weight of dimethoate compared to control. The testicular histology of animals treated with high doses of dimethoate generally showed span of Sertoli cells destruction and disorganization of the germinal epithelium. The lumen of seminiferous tubules of treated rats was generally poor in sperm. The results of this study confirmed that dimethoate seriously deteriorate the male reproductive system resulting in decreased fertility.
\end{abstract}

Keywords: Dimethoate, Spermatogenesis, Fertility, Testis Histology, Male Rats

\section{INTRODUCTION}

Dimethoate (DM) [(0, 0-dimethyl-S (N-methylcarbonyl methyl) phosphorodithioate)] is an organophosphate insecticide with numerous uses on field, agricultural crops and ornamentals (Hayes and
Laws, 1991). The extensive use of Dimethoate may pose a health hazard to animals and humans because of its persistence in soil and crops (IPCS/WHO, 1996). The residue of DM and its analog (omethoate) were found in many food stuffs including cow milk (Srivastava and Raizada, 1996). In mammals, the primary site of action

Corresponding Author: Ferdinand Ngoula, Department of Animal Science, Faculty of Agronomy and Agricultural Sciences, University of Dschang, PO Box: 188, Dschang, Cameroon 
of organophosphate pesticides is the central and peripheral nervous systems and its is by inhibiting acetylcholonesterase, a biochemical event that result in accumulation of endogenous acetylcholine at the nerve endings (Sarkar and Maitra, 1990; Gore, 2001). Several physiological and behavioral dysfunctions occur in animals after exposure to light doses of organophosphate pesticide (Ambali et al., 2011). Thus, the possibility that dimethoate can affect humans and wildlife in their natural habitats is of great concern. Dimethoate has been reported to cause developmental toxicity as well as reproductive failures in organisms upon repeated exposures. Developmental toxicity of dimethoate includes decreased number of implantations and live fetuses, incidences of resorptions and decreased fetal body weights (Farag et al., 2006). Reproductive toxicity of this pesticide on adult rodents of both sexes have been demonstrated. Irregularities of Estrous cycle and altered level of serum gonadotrophins have been reported in females (Kaur and Dhanju, 2005; Mahadevaswami and Kaliwal, 2002), while impairment of fertility, suppressed libido, semen quality deterioration, altered testosterone levels and testicular degeneration are few of the reports available in males (Farag et al., 2007; Sayim, 2007; Ngoula et al., 2007a; 2007b).

Dimethoate at $28 \mathrm{mg} \mathrm{kg}^{-1}$ was associated with a significant decreased of sperm count, mobility and viability and significantly increased the percent of morphologically abnormal spermatozoa compared with the controls (Abdallah et al., 2010).

There is abundant information relating to neurotoxic effects of Dimethoate. But less is known on their impact on males reproduction, notably on sperm characteristics, epididymis and testes structure and fertility. This study was therefore undertaking to access the effects of 3 months administration of lows dose of Dimethoate (LD50/30, LD50/20 and LD50/10) on the reproductive organs and fertility of adults male rats.

\section{MATERIALS AND METHODS}

\subsection{Animals}

24 Healthy Wistar adult male rats weighing between 275 and $300 \mathrm{~g}$ were used in this study. Animals were housed in wire cages $(50 \times 25 \mathrm{~cm}$ wide $\times 25 \mathrm{~cm}$ high), six per cage in a centralized animal care facility maintained at 20 to $25^{\circ} \mathrm{C}$ with an average relative humidity of $77 \pm 6 \%$. Animals were kept in a $12 \mathrm{~h}$ light dark cycle and provided ad libitum with water and a laboratory diet.

\subsection{Chemical}

Dimezyl used in this study is an insecticide of the organophosphate family, with the active ingredient, dimethoate (dithiophosphate $\mathrm{O}, \mathrm{O}$ and s-dimethyl methylcarbonylmethyl) concentrated at $400 \mathrm{~g} \mathrm{~L}^{-1}$. It has a molecular weight of 229.28. Dimezyl is manufactured by Chimac Agrifar Belgium.

\subsection{Experimental Desig}

Animals were randomly divided into four groups of 6 rats each and treated as follows: Group 1 was orally administered with $5 \mathrm{~mL} \mathrm{~kg}^{-1}$ of distilled water whilst Groups 2, 3 and 4 received Dimathoate at a dose equivalent to $0,3.66,5.50$ and $11 \mathrm{mg} \mathrm{kg}^{-1}$ body weight for 90 days. The doses used in the study were selected from a pilot study and represented 1/30,1/20 and 1/10 of LD50 value obtained in mice $\left(110 \mathrm{mg} \mathrm{kg}^{-1}\right)$. During the treatment, body weight and feed consumption were measured at 2 days intervals.

\subsection{Fertility Test}

Each male was allowed to undergo mating with 2 females (3-4 months old) of proven fertility during the last 10 days of treatment (as from day 80 of treatment). The vaginal smear was examined for the presence of sperm as a criteria for successful insemination and each spermpositive female was caged separately and observed after 21-24 days for deliver. Furthermore, pups were examined for litter size, litter weight, sex and viability. Fertility index [(number of pregnant animals/number of females mated $\times 100$ ], gestation index [number of pups born alive/number of total pups born] $\times 100$ and parturition index [number of females delivered/number of pregnant animals $] \times 100$ were also calculated according to the method of Kennedy et al. (1973) and Wernik et al. (1975).

\subsection{Serum and Organ Collections}

At the end of treatment (91th day), blood was collected by cardiac puncture from each rat under ether anesthesia. Serum was prepared and stored at $-20^{\circ} \mathrm{C}$ prior to analysis.

After killing the rats with exces dose of ether, organs like testes, epididymis, ventral prostate, vas deferens, seminal vesicles, liver and kidneys were carefully removed, free of adipose tissues, blotted dry and weighed separately. The left testes was then homogenized in a known volume of cold distilled water and aliquots of supernatant were kept at $-20^{\circ} \mathrm{C}$ prior to biochemical estimations of proteins, cholesterol and acid phosphatase.

\subsection{Sperm Density and Motility}

Immediately after the sacrifice of each rat by ether overdose, the right cauda epididymis was excised and 
minced in $10 \mathrm{~mL}$ of warm $\left(36^{\circ}\right) \mathrm{NaCl}$ solution for motility evaluation. About $20 \mu \mathrm{L}$ of this mixture were used to count motile and non-motile sperms (Olympus, $\times 40$ ). The percentage of motile spermatozoa was determined using the following formula: Percentage of mobile spermatozoa = [Number of mobile spermatozoa/Total number of counted spermatozoa] $\times 100$.

The sperm density was determined in the right cauda epididimis using a Bürker haemocytometer.

\subsection{Serum and Tissue Biochemical Analysis}

Total protein contents of serum and testes were determined by Biuret (Gornal et al., 1949) and Bradford (1976) methods respectively. Serum and intra-testicular total cholesterol were determined using a commercially available kit from Human Gesellschaft für Biochemical und Diagnostica mbH (Wiesbaden-Germany).

\subsection{Tissue Preparation and Histopathology}

The left testis was fixed in Bouin's fluid for 1 week, embedded in paraffin, cut at $5 \mu \mathrm{m}$ and stained with Harris haematoxylin and eosin (El-Kirdasy et al., 2014). The tissue sections were observed under a light microscope (Olympus, $\times 40$ ) for seminiferous tubule morphology and cellular harmony.

\subsection{Statistical Analysis}

Values are presented as Mean \pm SD. ANOVA was performed for comparison with post-hoc Duncan test. A $p$ value of $<0.05$ was considered statistically significant. Statistical analyses were performed with the aid of SPSS with Windows software programme (Release 19.01).

\section{RESULTS}

\subsection{Effects of Dimethoate on Feed Consumption and Body Weight Gain}

The effects of dimethoate on feed consumption and body weight gain are presented in Table 1. Feed consumption decreased significantly $(\mathrm{p}<0.05)$ with increasing doses of dimethoate. Similarly, the body weight gain significantly decreased in rats treated with dimethoate at different doses, compared to control group. When treated rats were considered, the decrease in body weight gain was more relevant in animals which received the highest dose of dimethoate $\left(11 \mathrm{mg} \mathrm{kg}^{-1}\right)$ compare to those treated with 3.66 and $5.6 \mathrm{mg} \mathrm{kg}^{-1}$ of body weight.

\subsection{Effects of Dimethoate on Relative Weight of Reproductive Organs}

The relative weight of reproductive organs after 90 days of dimethoate ingestion are summarized in Table 1. The relative weight of testes decreased with increasing doses of dimethoate. Statistical analysis showed significant differences $(p<0.05)$ for the values of this parameter recorded at the highest dose $\left(11 \mathrm{mg} \mathrm{kg}^{-1}\right)$ compared to the control group and the group that received the lowest dose $\left(3.66 \mathrm{mg} \mathrm{kg}^{-1}\right)$. The relative weight of epididymes was significantly $(\mathrm{p}<0.05)$ higher in rats treated with dimethoate, compared to control animals.

The relative weight of vas deferens significantly decreased $(\mathrm{p}<0.05)$ in rats treated with $5.5 \mathrm{mg}$ of dimethoate $/ \mathrm{kg}$ of body weight compared to control. On the other hand, the relative weight of ventral prostate increased with increasing doses of dimethoate. The statistical analysis showed significant differences $(p<0.05)$ between the values of this parameter recorded at the highest dose $\left(11 \mathrm{mg} \mathrm{kg} \mathrm{kg}^{-1}\right)$ compared those obtained at doses $0,3.66$ and $5.5 \mathrm{mg} \mathrm{kg}^{-1}$ of body weight. The considered dimethoate doses does not have any significant effect on seminal vesicles weight.

\subsection{Effects of Dimethoate on Sperm Characteristics, Biochemical Parameters and Fertility}

Table 2 summarize the effects of dimathoate on sperm characteristics, biochemical parameters and fertility.

\subsubsection{Sperm Characteristics}

The sperm density per cauda epididymis recorded after 90 days of treatment declined significantly $(\mathrm{p}<0.05)$ in rats treated with the different doses of dimethoate compared to control. Generally, the number of sperm per gram of epididymis and their mobility significantly declined $(\mathrm{p}<0.05)$ with increasing doses of dimethoate.

\subsubsection{Total Protein and Cholesterol Levels in Serum and Testes and Prostatic acid Phosphatase Activity}

The total serum protein levels decreased significantly $(p<0.05)$ with increasing doses of dimethoate. The level of protein in the testes was significantly $(p<0.05)$ lower in treatment groups than in control rats. The level of total cholesterol in the serum was significantly $(p<0.05)$ higher in animals in the control group compared animals in the treatment groups. 
Table 1. Effects of dimethoate feed consumption, body weight gain and relative weight of the sexual organs, liver and kidneys

\begin{tabular}{lcccc}
\hline & Doses of dimethoate $(\mathrm{mg} / \mathrm{kg})$ & & \\
& - & $3.66(\mathrm{n}=6)$ & $5.5(\mathrm{n}=6)$ & $11(\mathrm{n}=6)$ \\
\hline Organs & $0($ control $)(\mathrm{n}=6)$ & $124.89 \pm 23.63^{\mathrm{a}}$ & $102.30 \pm 19.38^{\mathrm{b}}$ & $84.36 \pm 29.39^{\mathrm{c}}$ \\
\hline Feed consumption $(\mathrm{g} / \mathrm{kg}$ rat/day) & $123.31 \pm 16.98^{\mathrm{a}}$ & $29.89 \pm 3.13^{\mathrm{b}}$ & $27.49 \pm 3.79^{\mathrm{b}}$ & $15.48 \pm 2.22^{\mathrm{c}}$ \\
Body weight gain $(\mathrm{g} / 100 \mathrm{~g}$ body weight $)$ & $40.37 \pm 3.88^{\mathrm{a}}$ & $1.05 \pm 0.06^{\mathrm{a}}$ & $1.02 \pm 0.06^{\mathrm{ab}}$ & $0.97 \pm 0.14^{\mathrm{b}}$ \\
Testes & $1.10 \pm 0.09^{\mathrm{a}}$ & $0.40 \pm 0.02^{\mathrm{b}}$ & $0.38 \pm 0.04^{\mathrm{b}}$ & $0.37 \pm 0.06^{\mathrm{b}}$ \\
Epididymis & $0.31 \pm 0.01^{\mathrm{a}}$ & $0.08 \pm 0.08^{\mathrm{a}}$ & $0.05 \pm 0.02^{\mathrm{b}}$ & $0.07 \pm 0.01^{\mathrm{ab}}$ \\
Vas deferens & $0.09 \pm 0.08^{\mathrm{a}}$ & $0.12 \pm 0.02^{\mathrm{a}}$ & $0.13 \pm 0.02^{\mathrm{a}}$ & $0.17 \pm 0.05^{\mathrm{b}}$ \\
Ventral prostate $_{\text {Seminal vesicles }}$ & $0.10 \pm 0.02^{\mathrm{a}}$ & $0.41 \pm 0.01^{\mathrm{a}}$ & $0.32 \pm 0.12^{\mathrm{a}}$ & $0.42 \pm 0.01^{\mathrm{a}}$ \\
\hline
\end{tabular}

$\mathrm{n}=$ number of rats

$\mathrm{a}, \mathrm{b}$ : Values with the same letter in a row are not significant $(\mathrm{p}>0.05)$

Table 2. Effects of dimethoate on sperm characteristics, biochemical and fertility parameters

\begin{tabular}{|c|c|c|c|c|}
\hline \multirow[b]{2}{*}{ Parameters } & \multicolumn{4}{|c|}{ Dimethoate doses (mg/kg/day) } \\
\hline & $0.00($ control $)(n=6)$ & $3.66(n=6)$ & $5.5(n=6)$ & $11(n=6)$ \\
\hline \multicolumn{5}{|c|}{ Sperm characteristics Sperm density $\left(\times 10^{6}\right)$} \\
\hline Per cauda epididymis & $113.00 \pm 21.00^{\mathrm{a}}$ & $70.71 \pm 22.67^{\mathrm{b}}$ & $61.45 \pm 10.54^{\mathrm{b}}$ & $57.76 \pm 20.86^{\mathrm{b}}$ \\
\hline Per g of cauda epididymis & $725.95 \pm 188.71^{\mathrm{a}}$ & $459.45 \pm 165.77^{\mathrm{b}}$ & $370.76 \pm 102.66^{\mathrm{b}}$ & $339.54 \pm 104.30^{\mathrm{c}}$ \\
\hline Sperm motility $(\%)$ & $92.73 \pm 2.93^{\mathrm{a}}$ & $83.39 \pm 4.89^{\mathrm{b}}$ & $79.25 \pm 5.10^{\mathrm{b}}$ & $69.36 \pm 6.10^{c}$ \\
\hline \multicolumn{5}{|l|}{ Biochemical parameters } \\
\hline Serum proteins $(\mathrm{mg} / \mathrm{mL})$ & $2.99 \pm 0.66^{\mathrm{a}}$ & $2.23 \pm 0.63^{\mathrm{b}}$ & $2.07 \pm 0.38^{c}$ & $1.6 \pm 0.32^{\mathrm{d}}$ \\
\hline Testes proteins $(\mu \mathrm{g} / \mathrm{g})$ & $39.44 \pm 7.60^{\mathrm{a}}$ & $28.2 \pm 3,96^{\mathrm{b}}$ & $19.77 \pm 3.63^{\mathrm{c}}$ & $23.44 \pm 5.15^{\mathrm{bc}}$ \\
\hline Serum cholesterol (mg/dL) & $78.63 \pm 14.94^{\mathrm{a}}$ & $57.84 \pm 8.74^{b}$ & $60.97 \pm 7.23^{\mathrm{b}}$ & $62.11 \pm 9.34^{\mathrm{b}}$ \\
\hline Testes cholesterol (mg/g) & $0.46 \pm 0.22^{\mathrm{a}}$ & $0.42 \pm 0.14^{\mathrm{ab}}$ & $0.14 \pm 0.18^{\mathrm{b}}$ & $0.23 \pm 0.17^{\mathrm{b}}$ \\
\hline Prostatic AP activity (U/g) & $0.37 \pm 0.09^{\mathrm{a}}$ & $0.26 \pm 0.06^{\mathrm{b}}$ & $0.22 \pm 0.11^{\mathrm{b}}$ & $0.11 \pm 0.06^{\mathrm{c}}$ \\
\hline \multicolumn{5}{|l|}{ Fertility parameters } \\
\hline Fertility index (\%) & $100 \pm 0.00^{\mathrm{a}}$ & $58.33 \pm 13.26^{\mathrm{b}}$ & $33.33 \pm 17.68^{c}$ & $22.22 \pm 14.10^{\mathrm{c}}$ \\
\hline Parturition index (\%) & $100 \pm 0.00^{\mathrm{a}}$ & $85.71 \pm 26.80^{\mathrm{a}}$ & $60.11 \pm 32.47^{\mathrm{b}}$ & $50.31 \pm 18.23^{\mathrm{b}}$ \\
\hline Gestation index (\%) & $100 \pm 0.00^{\mathrm{a}}$ & $100 \pm 0.00^{\mathrm{a}}$ & $86.2 \pm 44.12^{\mathrm{b}}$ & $75.41 \pm 35.19^{\mathrm{b}}$ \\
\hline Birth weight (g) & $4.63 \pm 0.22^{\mathrm{a}}$ & $4,23 \pm 0.19^{\mathrm{a}}$ & $4.32 \pm 0.44^{\mathrm{a}}$ & $4.69 \pm 0.39^{\mathrm{a}}$ \\
\hline Litter size & $7.30 \pm 2.40^{\mathrm{a}}$ & $4.21 \pm 1.10^{\mathrm{b}}$ & $4.50 \pm 0.92^{\mathrm{b}}$ & $4.04 \pm 1.20^{\mathrm{b}}$ \\
\hline Sex-ratio at birth & $50.72 \pm 5.20^{\mathrm{a}}$ & $49.12 \pm 7.20^{\mathrm{a}}$ & $47.30 \pm 3.12^{\mathrm{a}}$ & $48.73 \pm 4.56^{\mathrm{a}}$ \\
\hline
\end{tabular}

$\mathrm{a}, \mathrm{b}, \mathrm{c}, \mathrm{d}$ : Values with the same letter in a row are not significant $(\mathrm{p}>0.05)$

$\mathrm{n}=$ nomber of rats

AP: Acid Phospatase

All values $=$ mean \pm Standard Deviation

The total cholesterol level in the testes appeared higher in treated animals than in controls; significant differences $(\mathrm{p}<0.05)$ was obtained between the value of this parameter recorded in control rats and those obtained in rats force-feed with 5.5 and $11 \mathrm{mg} \mathrm{kg}^{-1}$ of body weight. In general, the prostatic acid phosphatase activity significantly declined $(\mathrm{p}<0.05)$ with increasing doses of dimethoate.

\subsubsection{Effects of dimethoate on the Fertility of Rats}

The fertility index generally declined significantly $(p<0.05)$ with increasing doses of dimethoate. The parturition index decreased significantly $(\mathrm{p}<0.05)$ in females rats matted males which received 5.5 and $11 \mathrm{mg}$ of dimethoate $/ \mathrm{kg}$ compared to those mated with males treated with 0 and $366 \mathrm{mg} \mathrm{kg}^{-1}$. The pup weight at birth was not affected by male mediated dimethoate treatment $(p>0.05)$. The litter size decreased significantly $(p<0.05)$ in females mated with males who received dimethoate compared to control. The sex ratio at birth was not significantly affected ( $p>$ 0.05 ) by dimethoate at different doses.

\subsubsection{Effects of Dimethoate on Testicular Histology}

In control rats, the testes contained normal semniferous tubules in which spermatogenesis is 
maintained. The germinal epithelium is well organized and the interstitial tissue of normal structure containing blood vessels (Fig. 1). In rats treated with dimethoate, the testicular structure was damaged. Among the reported damage, there was a dose-dependent depletion of sperm in the lumen of seminiferous tubules and destruction of their walls with the presence of empty bays between the germ cells. In addition, several structural changes was specific to certain doses. Thus, necrosis of germ cells were observed at doses $\geq 5.5 \mathrm{mg}$ $\mathrm{kg}^{-1}$ of body weight. An unsticking of the basal membrane of seminiferous tubules was noted in the testes of animals receiving the highest dose of dimethoate.
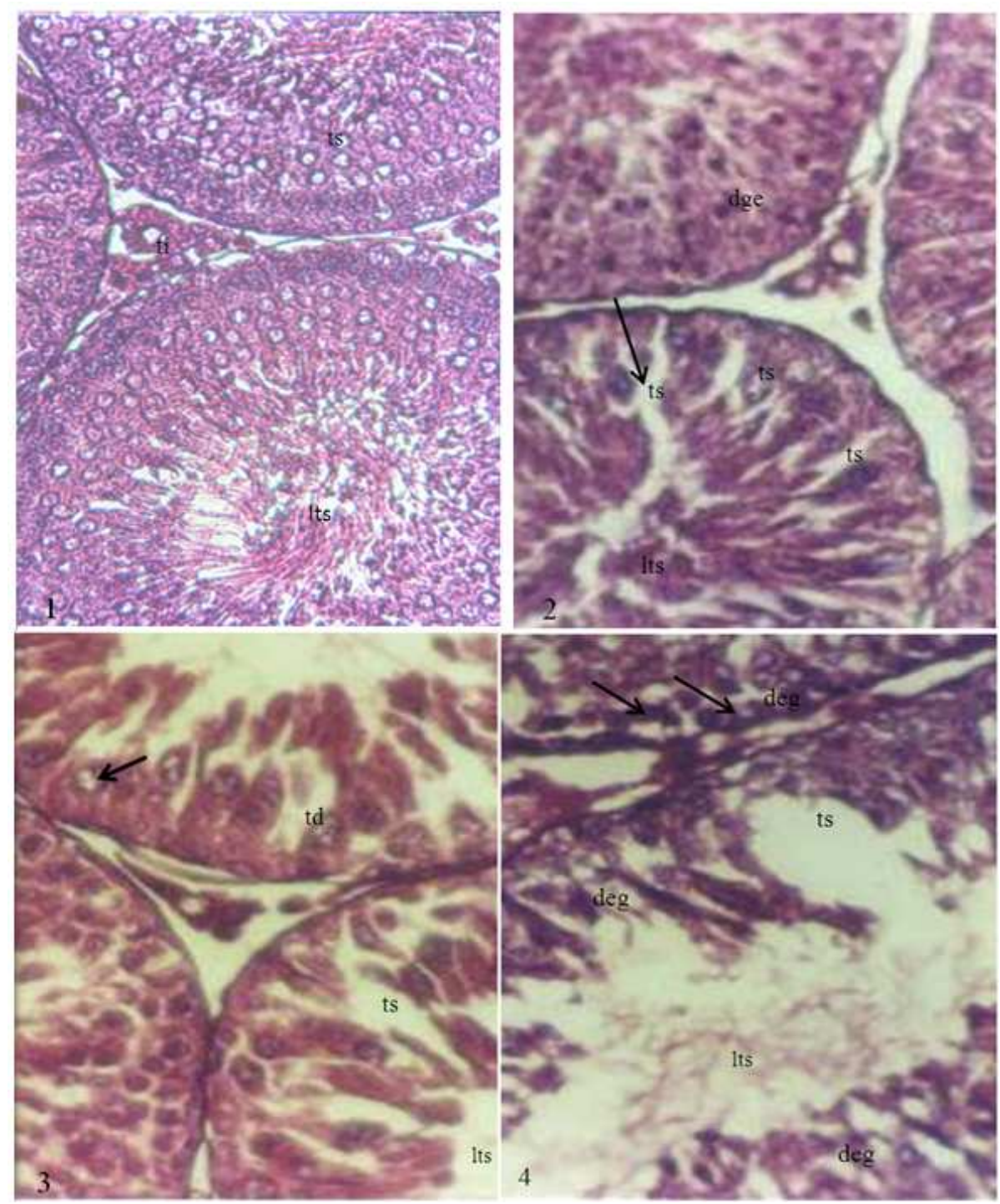

Fig. 1. Testes structure of control (1) and treated rats $\left[1\right.$ (3.66; 2 (5.50 and 3 (11.00) $\left.\mathrm{mg} \mathrm{kg}^{-1}\right]$ (HE X 400). 1. Seminiferous tubules (ts) and interstitial tissue (ti) has a normal aspect, the lumen of seminiferous tubules (1st) is very rich in sperms 2 . Germ cell degeneration $(\rightleftarrows)$, Sertoli cells destruction (ts), lumen of seminiferous tubules (lst) containing fewer sperm compared to control animals, disruption of the germinal epithelium (deg). 3. Sertoli cells destruction (ts), necrotic germ cells ( $\rightleftarrows$ ), lumen of seminiferous tubules very poor in sperms (lts). 4. Advanced destruction of the germinal epithelium (dge), necrosis of germ cells, lumen of tubes $(\rightleftarrows)$ very poor in sperm 


\section{DISCUSSION}

Administration of dimethoate to male rats caused a decrease in feed consumption, particularly at the highest dose (11 mg kg-1 body weight). These results are similar to the observations of Peiris et al. (1995) in rats treated with methamidophos and of Mehedi et al. (2009) in Swiss albinos mice treated with tartrazine. This decrease in feed consumption could be due to the decrease in metabolism, or inhibition of the hunger resulting in a lack of appetite or anorexia. Furthermore, the reduction in feed intake could explain the slower growth observed in this study. Indeed, in the case of insufficient feed intake, the non-availability of nutrients in the fluids causes the breakdown of proteins and fats for energy needs (Williams, 1994). There was a significant decrease in the relative weight of testis and vas deferens and a significant increase of the relative weight of epididymis, seminal vesicle and ventral prostate. Joshi and Bensal (2012) also reported a decrease in relative weight of testes, epididymis, seminal vesicle, ventral prostate in rats treated with organophosphate moncrotophos. The decrease in testicular weight may be due to a reduction in the tubule size, spermatogenic arrest and inhibition of steroid biosynthesis of Leydig cells, a site of steroid biosynthesis (Sujatha et al., 2001; Sanchez-Pena et al., 2004). The observed reduction in weight of accessory sex organs may be due to a reduction in bioavailability of estrogenic and/or antiandrogenic activities of insecticides. The decreased testosterone level in the treated animals confirms the results of (Joshi et al., 2003).

The administration of dimethoate to adult male rats generally led to a decreased in total protein in the serum and/or testicles. Tripathi and Singh (2004) also noted a significant decrease of the level of tissue proteins in freshwater snails (L. acuminata) exposed to carbaryl. Proteins are must important components of living organisms and the playing a vital role in body building, physiology of the cell and cell metabolism (Mommsen and Walsh, 1992). The decrease in protein levels could be due to a degradation for metabolic needs. Under stress conditions, protein consumed is not stored in the tissue (Palanichamy, 1990) and are directly mobilized to produce glucose which is an energy made available by the process of gluconeogenesis (Vasanthi et al., 1990). Thus, lower protein levels could be attributed to the destruction/cellular necrosis and to a subsequent deterioration of the mechanism of protein synthesis. In addition, serum and testes cholesterol were decreased in rats given dimethoate. Cholesterol is the main precursor of steroidogenesis produced mainly in the liver from
LDL and HDL (Robel, 2001; Johnson and Everitt, 2002). The decline in serum may be related to the adverse effects of this insecticide on the liver, resulting in low production. Walsh and Stocco (1998) also showed that dimethoate lower testosterone levels by blocking testicular steroidogenesis in Leydig cells by decreasing the expression of the protein that regulates steroidogenesis. Acid phosphatase is a lysosomal enzyme that plays an important role in catabolism, pathological necrosis, autolysis and phagocytosis (Abou-Donia, 1978). The measure of the activity of prostatic acid phosphatase in response to the administration of dimethoate showed a dose-dependent inhibition of this activity after 90 days of treatment. Har (1982) and Tripathi and Singh (2004) also noted a decrease in activity of acid phosphatase, respectively, in rats treated with busulphan and in freshwater snails exposed to carbaryl. This is due to prostatitis and/or testicular lesions caused by this insecticide. Indeed, these lesions causing a decreased of prostate markers rate such as citrate, zinc and acid phosphatase (WHO, 2010). Moreover, it is well established that sexual differentiation, growth and maintenance of the epididymis, ventral prostate and seminal vesicles are androgen-dependent processes (De-Krester et al., 1987; Dacheux et al., 1998; Tostain et al., 2004). It has been shown that a decrease in serum testosterone induced a decrease in secretory activity of the mass of the sexual tissues (Wilson, 1995; Kashiwagi et al., 2005). Accessory reproductive organs are structures rich in 5 alpha-reductase, an enzyme responsible for converting testosterone to dihydrotestosterone is the active hormone (Johnson and Everitt, 2002). The conversion of testosterone to 5 alpha-dihydrotestosterone by 5 alpha-reductase in the cells of certain accessory reproductive organs or the binding testosterone or dihydrotestosterone to androgen receptors and the induction of selective genes are two important aspects of the androgen action on target cells that could be disrupted by toxic agents. Thus, the decrease of phosphatase activity could be the result of decreased production and secretion of testosterone and/or nonconversion of testosterone into more active metabolites.

In adult male rats exposed to dimethoate, epididymal sperm concentration decreased with increasing doses of the pesticide. A decrease in epididymal sperm density was also reported by Thonneau et al. (1996) in rats gavaged with quinalphos; by Sobarzo and Bustos-Obregeon (2000); Bustos-Obregon and Gonzallez Harmanzaba (2003) in rats that received parathion and Kamijima et al. (2004) among pesticide applicators. This depreciation in epididymal sperm concentration may be related to 
inhibition of the biosynthesis of testosterone as mentioned above or to the cessation of the release of FSH and LH in the brain. Indeed, Short and Colborn (1999) and Gwynne (2000) have shown that organophosphates and carbamates pesticides reduce the activity of acetylcholinesterase (enzyme), thus blocking transmission of nerve impulses. This effect could prevent the release of FSH and $\mathrm{LH}$ from the pituitary, resulting in reduced production of sperm in the testicles. This study also revealed a decrease in the percentage of motile sperm in rats treated with dimethoate. A similar result was recorded by Kamijima et al. (2004), among pesticide applicators regularly exposed to organophosphates. This could be due to low production of epididymal proteins. Indeed, these proteins are essential for sperm motility (Dadoune and Demoulin, 2001).

After treating the animals for 90 days with diméthoate solutions, fertility, gestation and parturition indices, weight and sex ratio (M/F) of pup at birth have generally decreased compared to control. Savitz et al. (1997); Petrelli and Figa-Talamanca (2001) and Petrelli et al. (2003) also noted a general decline of fertility in spouse of subjects exposed to pesticides. In addition, Blakley et al. (1989) recorded low fetal weight and increased fetal abnormalities in female mice that were crossed with males treated with Tordon 202c (herbicide). The decline in fertility recorded in this study may be due to inhibition of spermatogenesis and/or decrease in sperm motility.

The microscopic observation of tissue structure of testes of rats fed dimethoate $\left(3.66,5.5\right.$ and $11 \mathrm{mg} \mathrm{kg}^{-1}$ body weight) show span of Sertoli cells destruction with impairment of spermatogenesis. Chakroun et al. (2002) obtained similar results, but in rats exposed to nickel. The Sertoli cell is a fundamental component of the structural architecture of the seminiferous epithelium. It provides physical support to germ cells hidden in its cytoplasm (Clermont, 1993). Its basic function is to create a microenvironment suitable for the development of germ cells ( $\mathrm{Li}$ and Heindel, 1998). Any violation of its integrity adversely will affect spermatogenesis. This could explain the loss of in sperm in the lumen of epididymal channels recorded in this study.

The testicular histology of rats exposed to dimethoate also revealed necrosis of germ cells (dose $5.5 \mathrm{mg} \mathrm{kg}^{-1}$ of body weight and over) and degeneration of the germinal epithelium with reduction of cell number $\left(11 \mathrm{mg} \mathrm{kg}^{-1}\right.$ body weight). Bustos-Obregon and GonzalezHormazabal (2003) also noted a decrease of the number of germ cells in testes of mice exposed to malathion. Chakroun et al. (2002) have also noted the presence of apoptotic cells in the testes of rats that ingested 50 and 250 ppm of nikel for 90 days. Dimethoate would be cytotoxic. This cytotoxic effect seems to be exerted by a phenomenon of germ cells necrosis (Akbarsha et al., 2000).

Greater precautions must be taken in order to minimize the harmful side effects of organophosphorus compounds on all the surroundings to decrease the incidence of environmental pollution. So we have to be aware of detrimental effects of dimethoate, at least in primary setting, on male reproductive system.

\section{CONCLUSION}

In conclusion, our results have showed that the administration of dimethoate, a widely use organophosphate insecticide, by oral route to adult male rats at the doses of $3.66,5.50$ and $11.00 \mathrm{mg} / \mathrm{kg} / \mathrm{day}$ during 90 days disrupted spermatogenesis and reduced the fertility. Finaly, it is recommended that the use of dimethoate must be limited due to its hazardous effects.

\section{REFERENCES}

Abdallah, F.B., A.B. Slima, I. Dammak, L. KeskesAmmar and Z. Mallek, 2010. Comparative effects of dimethoate and deltamethrin on reproductive system in mice. Andrologia, 42: 182-186. DOI: 10.1111/j.1439-0272.2009.00976.x

Abou-Donia, M.B., 1978. Increased acid phosphatase activity in hens following and oral dose of leptophos. Toxicol. Lett., 2: 199-203. DOI: 10.1016/0378-4274(78)90067-X

Akbarsha, M.A., P.N.L. Latha and P. Murugaian, 2000. Retention of cytoplasmic droplet by rat cauda epididymal spermatozoa after treatment with cytotoxic and xenobiotics agents. J. Repro. Fertil., 120: 385-390. PMID: 11058454

Ambali, S.F., M. Shittu, J.O. Ayo, K.A.N. Esievo and S.A. Ojo, 2011. Vitamin C alleviates chronic chlorpyrifos induced alterations in serum lipids and oxidative parameters in male wistar rats. Am. J. Pharmacol. Toxicol., 6: 109-118. DOI: 10.3844/ajptsp.2011.109.118

Blakley, P.M., J.S. Kim and G.D. Firneisz, 1989. The effects of paternal subacute exposure to tordon 202 $\mathrm{C}$ on foetal growth and development in CD-1 mice. Teratology, 39: 237-241. DOI: 10.1002/tera.1420390305

Bradford, M.N., 1976. A rapid and sensitive method for the quantification of microgram quantity of proteindye binding. Analyt. Biochem., 72: 248-254. DOI: 10.1016/0003-2697(76)90527-3 
Bustos-Obregon, E. and P. Gonzallez-Hormanzabal, 2003. Mice testicular damage elicited by malathion. Int. J. Morphol., 21: 155-159. DOI: 10.4067/S071795022003000200010

Chakroun, H., N. Hfaiedh, F. Makni-Ayadi, F Guermazi and A. Kammoun at al., 2002. Nickel et fertilité chez le rat. Sexologies, 12: 59-65.

Clermont, Y., 1993. Introduction to Sertoli Cell. In: The Sertoli Cell. Cache River Press, Russel L.D. and M.D. Griswold (Eds.).

Dacheux, J.L., X. Druart and P. Syntin, 1998. Role of epididymal secretory proteins in sperm maturation with particular reference to the boar. J. Reproduct. Fertility, 53: 99-107. PMID: 10645270

Dadoune, J.P. and A. Demoulin, 2001. Structure et Fonction Du Testicule. In: La reproduction chez les mammiferes et l'homme, Thibault, C., snd M.C. Levasseur, (Eds.), Editions Quae, Paris, ISBN-10: 272980417X.

De-Krester, D.M., C.L. Au and D.M. Robertson, 1987. The Physiology of Inhibin in the Male. In: InhibinNon-Steroidal Regulation of Follicle Stimulating Hormone Secretion, Burger, H.G., De Kreter, D.M., T.K. Finndlay and M. Igrashi (Eds.), Raven Press, ISBN-10: 0881673234, pp: 42-149.

El-Kirdasy, A.F., M.A. Nassan, A.A.A. Baiomy, T.A. Ismail and M.M. Soliman et al., 2014. Potential ameliorative role of n-acetylcysteine against testicular dysfunction induced by titanium dioxide in male albino rats. Am. J. Pharmacol. Toxicol., 9: 2938. DOI: 10.3844/ajptsp.2014.29.38

Farag, A.T., A.F. El-Aswad and N.A. Shaaban, 2007. Assessment of reproductive toxicity of orally administered technical dimethoate in male mice. Reprod. Toxicol., 23: 232-238. DOI: 10.1016/j.reprotox.2006.12.003

Farag, A.T., T.A.Z. Karkour and A.E. Okazy, 2006. Developmental toxicity of orally administered technical dimethoate in rats. Birth Defects Res., 77: 40-46. PMID: 16496292

Gore, A.C., 2001. Environmental toxicant effects on neuroendocrine function. Endocrine, 14: 235-246. DOI: 10.1385/ENDO:14:2:235

Gornal, A.G., G.S. Bardwil and M.M. David, 1949. Determination of serum proteins by means of the biuret reaction. J. Biol. Chem., 177: 751-766. PMID : 18110453

Gwynne, L., 2000. Mixed messages: Pesticides that Confuse Hormones. 1st Edn., Pesticide Action Network (PAN) UK., Briefing.

Har, D.K., 1982. Biochemical alteration in male accessory sex glands after the administration of an alkylating agent Busulphan. Ind. J. Pharmacol., 14: 281-286.
Hayes, W.J. and E.R. Laws, 1991. Handbook of Pesticide Toxicology. 1st Edn., Academic Press, San Diego, CA., ISBN-10: 0123341604, pp: 1523.

IPCS/WHO, 1996. Principles and Methods for Assessing Direct Immunotoxicity Associated with Exposure to Chemicals. 1st Edn., Geneva, Switzerland.

Johnson, M.H. and B.J. Everitt, 2002. Reproduction. D Boeck Université. S.A. Paris.

Joshi, S.C. and B. Bansal, 2012. Reproductive toxicity of monocrotophos in male rats. Int. J. Toxicol. Applied Pharmacol., 2: 6-11.

Joshi, S.C., R. Mathur, A. Gajraj and T. Sharma, 2003. Influence of methyl parathion on reproductive parameters in male rats. Environ. Toxicol. Pharmacol., 14: 91-98. DOI: 10.1016/S1382-6689(03)00043-7

Kamijima, M., H. Hibi, M. Gotoh, K.I. Taki and I. Saito et al., 2004. A survey of semen indices in insecticide sprayers. J. Occupat. Health, 46: 109118. DOI: 10.1539/joh.46.109

Kashiwagi, B., Y. Shibata, Y. Ono, R. Suzuki and S. Honma et al., 2005. Changes in testosterone and dihydrotestosterone levels in male rat accessory sex organs, serum and seminal fluid after castration: establishment of a new highly sensitive simultaneous androgen measurement method. J. Androl., 26: 586-591. DOI: 10.2164/jandrol.04164

Kaur, S. and C.K. Dhanju, 2005. Biochemical effects of some organophosphorus pesticides on the ovaries of albino rats. Indian J. Physiol. Pharmacol., 49: 148152. PMID: 16170982

Kennedy, G.L., P. John, J. Frawley and J.C. Calandra, 1973. Multigeneration reproductive effects of three pesticides in rats. Toxicol. Applied Pharmacol., 25: 589-596. DOI: 10.1016/0041-008X(73)90029-X

Li, L.H. and J.J. Heindel, 1998. Sertoli Cell Toxicants. In: Reproductive and Developmental Toxicology. Korach, K.S. (Ed.), CRC Press, ISBN-10: 1420002899.

Mahadevaswami, M.P. and B.B. Kaliwal, 2002. Effect of dimethoate administration schedules on compensatory ovarian hypertrophy, follicular dynamics and estrous cycle in hemicastrated mice. J. Basic Clin. Physiol. Pharmacol., 13: 225-248. DOI: 10.1515/JBCPP.2002.13.3.225

Mehedi, N., S. Ainad-Tabet, N. Mokrane, S. Addou and C. Zaoui et al., 2009. Reproductive toxicology of tartrazine (FD and C Yellow No. 5) in Swiss Albino Mice. Am. J. Pharmacol. Toxicol., 4: 130-135. DOI: 10.3844/ajptsp.2009.130.135

Mommsen, T.P. and P.J. Walsh, 1992. Biochemical and environmental perspectives on nitrogen metabolism in fishes. Experientia, 48: 583-593. DOI: 10.1007/BF01920243 
Ngoula, F., P. Watcho, M.C Dongmo, A. Kenfack and P. Kamtchouing et al., 2007b. Effects of pirimiphosmethyl on the fertility of adult male rats. Afr. Health Sci., 7: 3-9. PMID: 17604518

Ngoula, F., P. Watcho, S. Bouseko, A. Kenfack and J. Tchoumboue et al., 2007a. Effects of propoxur on the reproductive system of male rats. Afr. J. Reproduct. Health, 11: 125-132. DOI: $10.2307 / 30032495$

Palanichamy, B.S., 1990. Impact of agricultural (ammonium chloride) fertilizer on physiology and biochemistry of fresh water teleost fish (Oreochromis mossambicus). J. Ecobiol., 2: 97-106.

Peiris, L.D.C., Y.N.A. Jayatunga, W.D. Ratnasooriya, 1995. Antireproductive effects in male rats exposed to methamidophos. Ceylon J. Sci., 24: 53-59.

Petrelli, G. and I. Figa-Talamanca, 2001. Reduction in fertility in male greenhouse workers exposed to pesticides. Eur. J. Epidemiol., 17: 675-677. DOI: 10.1023/A:1015511625099

Petrelli, G., I. Figa-Talamanca, L. Lauria and A. Mantovani, 2003. Spontaneous abortion in spouses of greenhouse workers exposed to pesticides. Environ. Health Perspect. Med., 8: 77-81. PMID: 21432103

Robel, P., 2001. la stéroïdogénèse: Les Enzymes et la Régulation de Leur Expression Génomique. In: La Reproduction chez les Mammifères et L'homme, Thibaullt, C. and M.C. Levasseur (Éds.), INRA Editions, Paris.

Sanchez-Pena, L.C., B.E. Reyes, L. Lopez-Carrillo, R. Recio and J. Moran-Martinez et al., 2004. Organophosphorous pesticides exposure alters sperm chromatin structure in Mexican agricultural workers. Toxicol. Applied Pharmacol., 196: 108113. DOI: 10.1016/j.taap.2003.11.023

Sarkar, R. and S.K. Maitra, 1990. Responses of adrenal medulla to oral administration of organophosphorus pesticides in roseringed parakeets Psittacula krameri borealis (Neumann). Eur. Arch. Biol., 101: 469-480.

Savitz, D., T. Arbukle, D. Kaczor and K.M. Curtis, 1997. Male pesticide exposure and pregnancy outcome. Am. J. Epidemiol., 146: 1025-1036. DOI: 10.1093/oxfordjournals.aje.a009231

Sayim, F., 2007. Histopathologic effects of dimethoate on testis in rats. Bull. Environ. Contam. Toxicol., 78: 479-484. DOI: 10.1007/s00128-007-9196-5

Short, P. and T. Colborn, 1999. Pesticides use in the U.S. and polity implications. Toxicol. Indus. Health, 15: 240-275. DOI: 10.1191/074823399678846736
Sobarzo, C. and E. Bustos-Obregeon, 2000. Sperm quality in mice acutely treated with parathion. Asian J. Androl., 2: 147-150. PMID: 11232794

Srivastava, M.K. and R.B. Raizada, 1996. Development effect of technical dimethoate in rats: Maternal and fetal toxicity evaluation. Ind. J. Exp. Biol., 34: 239333. PMID: 8698421

Sujatha, R., K.C. Chitra, C. Latchoumycandane and P.P Mathur, 2001. Effect of lindane on testicular antioxidant system and steroidogenic enzymes in adult rats. Asian J. Androl., 3: 135-138. PMID: 11404799

Thonneau, P., L. Multigner, B. Ducot, A.Clavert and A. Spir, 1996. Pesticides and Male Fertility Current Knowledge and Epidemiological Approach. In: Research in Male Gamete: Production and Quality. Hamammah, R., (Eds). INSERM.

Tostain, J., D. Rossi and P.M. Martin, 2004. Physiologie des androgènes chez l'homme adulte. Progrès Urologie, 14: 639-660. PMID: 15747614

Tripathi, P.K. and A. Singh, 2004. Carbaryl induced alteration in reproduction and metabolism of fresh water snail Lymnaea acuminate. Pesticide Biochem. Physiol., 79: 1-9. DOI: 10.1016/j.pestbp.2003.11.003

Vasanthi, R., P. Baskaran and S. Palanichamy, 1990. Influence of carbofuran on growth and protein conversion efficiency in some fresh water fishes. J. Ecobiol., 2: 85-88.

Walsh, L.P. and D.M. Stocco, 1998. The effects of roundup and dimethoate on steroidogenesis acute regulatory (Star) protein in mouse MA-10 Leydig cells. Proceedings of the Society For the Study of Reproduction, Aug. 8-11, College Station, Texas Madison.

Wernik, T., B.M. Lamman and J.L. Franx, 1975. Chronic toxicity Teratologic and reproduction studies with hair dyes. Toxicol. Applied Pharmacol., 32: 450-60. DOI: 10.1016/0041-008X(75)90110-6

WHO, 2010. WHO Laboratory Manual for the Examination and Processing of Human Semen. 5th Edn, World Health Organization, ISBN-10: 9241547782, pp: 287.

Williams, S.R., 1994. Essentials of Nutrition and diet Therapy. 6th Edn., Mosby, Boston, ISBN-10: 0801679230, pp: 521.

Wilson, M.J., 1995. Toxicology of the Male Accessory Sex Organs and Related Glands. In: Reproductive Toxicology. Witorsch, R.J. (Ed.), Raven Press, New York, ISBN-10: 0781702259, pp: 123-139. 